\title{
The Clan Chattan
}

\section{Author(s): A. Maclean Sinclair}

Source: The Celtic Review, Vol. 8, No. 29 (Apr., 1912), pp. 1-7

Stable URL: http://www.jstor.org/stable/30022107

\section{Accessed: 10-06-2016 05:42 UTC}

Your use of the JSTOR archive indicates your acceptance of the Terms \& Conditions of Use, available at

http://about.jstor.org/terms

JSTOR is a not-for-profit service that helps scholars, researchers, and students discover, use, and build upon a wide range of content in a trusted digital archive. We use information technology and tools to increase productivity and facilitate new forms of scholarship. For more information about JSTOR, please contact support@jstor.org. 


\section{THE CELTIC REVIEW}

APRIL 1912

\section{THE CLAN CHATTAN}

\section{Rev. A. Maclean Sinclair \\ The Old Clan Chattan}

Gillecattan was born sometime between 900 and 950 A.D. $\mathrm{He}$ was the son of Gallbrait, son of Diarmad the Lector. His successors in the line of descent were as follows: Nectan, Seth, Suibhne, Muireach, Donald, Malcolm, Gilchrist, Ferchar and Seth. Donald, son of Muireach, was born about the year 1120, and was known as an Caimhghille. Caimh stands for Caemh or Coimh, gentle, handsome, or else for camh, strong, powerful. Gille means a young man. Donald was probably both strong and handsome. $\mathrm{He}$ was chief of the Clan Chattan, and the progenitor of Clann a Chaimhghille, which would be known in English as the Clan Chewill or Clan Kevill. Donald had two sons, Gillemoluaig and Malcolm. Gillemoluaig and Seth, son of Malcolm, appear on record between 1224 and 1233. They were living in Badenoch, on lands which belonged to the Bishop of Moray. Seth, son of Ferchar, son of Gilchrist, son of Malcolm, had two sons, Ferchar and Leod. Ferchar, son of Seth, was succeeded by his son Seth, who died before the year 1338, and was buried at Dalnafert. Seth, son of Leod, had a son named Suibhne, and probably a son named John. Lachlan, son of Suibhne, was born about 1360, and was chief of the old Clan Chattan, or Clan Chewill, in vor. VIII. 
1385, the year about which the Skene Manuscript was written.

In 1390 we find Slurach and the whole Clan Chewill charged with taking part with Stewarts, Duncansons, and others in making a raid into the Braes of Angus, and slaying Sir Walter Ogilvy and sixty of his followers in a skirmish which took place. Sir Walter was sheriff of Angus, and was trying to drive the invaders away. Slurach is a misreading for Muirach. There never was such a name as Slurach.

Whilst Lachlan, son of Suibhne, was nominal chief of the clan Chewill in 1390, Muireach, who was probably a brother of Lachlan, was their fighting leader and their real chief. Lachlan married a daughter of Lord Lovat, and had by her Ferchar and Margaret. He died in 1407. Ferchar, his son, was born probably about 1390. Ferchar married a daughter of the laird of Innes, and had Duncan and other children. He died in 1417.

\section{The Clan Vuirich}

r. Muireach, the Slurach of 1396, was born about 1365 . $\mathrm{He}$ was a man of ability and energy, and qualified for leading a clan in the rough days in which he lived. He was the progenitor of the Clan Vuirich, who are just the Clan Chewill under a new name.

II. Duncan, who was probably the second or third son of Muireach, studied for the Church, and was known as Duncan Person or Parson. He was unquestionably a man of ability and determination. He was with the Lord of the Isles in Lochaber, when the latter was attacked and defeated by James I. in 1429, and was taken prisoner. He was then chief of the Clan Chewill, and was probably the only lawful son of his father left alive. He was confined in Tantallon Castle in 1431, and had for companions Alexander, Lord of the Isles, Lachlan Bronnach Maclean of Duart, Torquil Macneill of Gigha, and Terlach MacFerchar. Lachlan Bronnach's father and Alexander of the Isles were 
first cousins. Torquil Macneill was by origin a Maclean, and was related to Lachlan Bronnach. Terlach MacFerchar was chieftain of the Macleans of Urquhart and was also related to Lachlan Bronnach. Duncan Parson was related to Terlach Mac Ferchar.

It may be regarded as certain that when Duncan Parson found himself in the position of chief of the Clan Chewill he ceased to act as priest. He took as his wife Isabel, daughter of Ferchar, son of Lachlan Mackintosh, the chief who died in 1407, and had by her two sons, Ewen Ban his successor and Bean of Brin, who appears on record in 1490.

III. Ewen Ban was born about 1430. He was married and had three sons, Kenneth, John and Gillies.

Iv. Kenneth, son of Ewen Ban, had two sons, Duncan and Donald.

v. Duncan, son of Kenneth, succeeded his father in Cluny.

vI. Andrew, son of Duncan, was born about 1520. He appears on record as tenant in Cluny in 1591 and 1603.

vir. Ewen, son of Andrew, had two sons, Andrew and John of Nuide.

Andrew, son of Ewen, was born about 1575, and fought at the battle of Glenlivet in 1594. He appears on record as laird of Cluny in 1609. Ewen Og, son of Andrew, was born probably about 1610. He married Ann, daughter of Duncan Forbes of Culloden, in 1641. He joined Montrose in 1645 with three hundred men of his own kin, and distinguished himself as a brave and loyal warrior. He remained with Montrose whilst the war continued. He died in 1647, leaving two sons, Andrew and Duncan. His father survived him about three years. Andrew, elder son of Ewen $\mathrm{Og}$, succeeded his father in Cluny, and his grandfather in the chiefship of the clan Vuirich. He died in 1672, and was succeeded by his brother Duncan, who died without male issue in 1722 .

vIII. John of Nuide was married in 1613, and appears on record as a cautioner or surety in 1641 . 
Ix. Donald, son of John, received a charter of Nuide in 1643.

x. Ewen, son of Donald, succeeded his father in Nuide. $\mathrm{He}$ married a daughter of Lachlan Macpherson of Kinrara.

XI. Lachlan, son of Ewen, succeeded his father in Nuide. He succeeded Duncan of Cluny, both in Cluny and the chiefship of the Macphersons in 1722. He married Jean, daughter of Sir Ewen Cameron of Lochiel, and had by her Ewen his successor. He died in 1746.

XII. Ewen of Cluny joined Prince Charles in 1745. He was a strong and active man. He married a daughter of Lord Lovat, and had by her Duncan his heir. $\mathrm{He}$ succeeded in getting out of the land of King George and the Duke of Cumberland in 1755. He died at Dunkirk in 1756. Duncan, his successor, was born in 1750 in a kiln for drying grain, the Georgites having burnt his father's house.

Between 1450 and 1500 the descendants of Muireach, father of Duncan Parson, began to call themselves Macvurichs in Gaelic and Macphersons in English. On the roll of clans in 1594, we find the Clan Chattan, Clan Chewill, Clan Chamron, Macinphersons, Grants, and others. In 1645 the gallant Ewen Og made the Macphersons famous in Scotland as a fighting clan. Shortly afterwards the Mackevils, or the Clan Chewill, quietly passed out of sight. What became of them? They just made Macphersons of themselves.

\section{The New Clan Chattan}

The new Clan Chattan or Mackintoshes are a branch of the old Clan Chattan. They are descended from Seth, son of Gilchrist, son of Aigcol, son of Ewen, great-grandson of Neil, a descendant of Gillecattan.

I. Seth, son of Gilchrist, was born about the year 1170 . His descendants would be known in Gaelic as Clann Sheath 
or Sheagh, and in English as Clan Hay or Hah. Shaw as a Highland name has no connection in meaning with the English name Shaw; it is simply an Anglicised form of Seth.

As it may seem impossible to those who cannot read Gaelic to get Hay or Hah out of Sheath or Sheagh, I may state that, so far as sound is concerned, sh and th in Gaelic are simply $h$, that $e a$ is sounded like $e$ in met, and that $g h$ is sounded almost like $y$ in English.

II. Ferchar, son of Seth, was toiseach or seneschal of Baidenach, and appears on record as a witness in 1234. He had two sons, Seth and Gillemichael. Seth was succeeded by his son Ferchar. Seth, son of Ferchar lived at Dalnafert, and died sometime before the year 1338.

III. Gillemichael, son of Ferchar, had two sons, Ferchar and William. Ferchar was killed about 1271. He left a son named Angus.

Iv. William, second son of Gillemichael, was succeeded by his son Ferchar.

v. Ferchar, son of William, had William and other sons.

vI. William, son of Ferchar, succeeded his father as toiseach of Badenach. He had three sons, Ferchar, William, and Donald. Ferchar was molesting the bishop of Aberdeen in 1382, possibly by taking away some of the cattle and sheep on the bishop's lands, and, fortunately for those who take an interest in clan history, got his name put on record. He is described as Ferchar Mac Toschy or Ferchar, son of the Toiseach. He had a daughter who was married to Terlach Maclean in Glen Urquhart, eldest son of Hector Reaganach of Lochbuie. Terlach and his wife had three children, Ferchar and two daughters. One of the daughters was married to Rory Macneil of. Barra. The other daughter was the mother of Donald, first Maclean of Ardgour. Thus, then, the Macneils of Barra and the Macleans of Ardgour are both descended from the fiery Ferchar MacToschy. I often read in Skene's Celtic Scotland about Ferchar and his doings; but I never knew until I 
was writing this article that $I$ am one of his descendants. Such, however, must be the case, for I am certainly descended from Donald of Ardgour.

vII. William, second son of William, son of Ferchar, succeeded his father in the line of descent. He handfasted with Renilda, daughter of Donald Dubh MacEwan vic Donald vic Gillony, and had by her two sons, Angus and Donald. He married, first, Florence, daughter of the thane of Calder, and had by her Lachlan and Mora. He married, secondly, Margaret, daughter of Rory Mor Macleod of Lewis by a daughter of the Lord of the Isles, and had by her Malcolm Beg and four daughters.

virr. Lachlan succeeded his father as chief of the Clan Hay or Macintoshes. He married Agnes, daughter of Fraser of Lovat, and had by her Ferchar and Margaret. He died in 1407. Ferchar was probably only seventeen or eighteen years of age when his father died. He married Egidia Innes, and had by her Duncan, Malcolm, Ferchar, and a daughter.

Ix. Malcolm Beg, second son of William, son of William, was born about 1385. He was an able, energetic, and shrewd man. He was elected chief of the Macintoshes in 1409. He commanded the left wing of the army of the Lord of the Isles at the battle of Harlaw in 1411, the right wing being in charge of Hector Roy Maclean of Duart. He supported King James against the Lord of the Isles in 1429, and thus won the king's favour. He obtained a lease of the barony of Moy in 1437, and a heritable right to Rait and Geddes in 1442. He received a charter of a number of lands in Lochaber in 1443, and a charter of the bailliary of Lochaber in 1447. He married Mora, daughter of Macdonald of Moydart, and by her had Duncan, Lachlan Badenach, Allan and Malcolm. He died in 1457.

x. Duncan, son of Malcolm Beg, married Florence, daughter of Alexander, Lord of the Isles, and had by her Ferchar his successor. He appears in a bond of friendship 
written in 1467 as Duncan Macintosh, chief and captain of the Clan Chattan. He died in 1496. He was not chief of all the Clan Chattan; he was chief only of the Macintoshes, or new Clan Chattan.

\section{Correction}

In an article published in this Review in July 1906, I held that the combatants on the North Inch of Perth in 1396 were the Clan Chattan and the Clan Cameron. I have given up that view, and have come to the conclusion that the combatants were the Clan Chewill and the Clan Heth. The chiefs of the Clan Chewill or Old Clan Chattan, had been captains of the Clan Chattan, and desired to remain captains ; whilst the chiefs of the Clan Heth, or New Clan Chattan, wanted to oust them and get the captaincy of the Clan Chattan for themselves. The object of the fight on the North Inch was, from the point of view of the combatants, to settle the dispute about the captaincy of the Clan Chattan. From the king's point of view, however, its object was to punish the Clan Chewill and the Clan Heth for their past raids, robberies, and slaughters, and to lead them to refrain for the future from molesting their fellow-men. In the raid made by the Clan Chewill and others into the Braes of Angus in 1390 there were sixty persons slain. In the fight on the North Inch of Perth in 1396 there were sixty persons present whose business it was to kill one another. 